\title{
Teacher Profile: The Knowledge and the Identity Practices
}

\author{
Alberto Albuquerque*, Paulo Sa, Agata Aranha and Rui Resende
}

Av. Carlo Oliveira Campos, Castelo da Maia 4475-690 Aviso S. Pedro University Institute of Maia

\begin{abstract}
This study aimed at finding an articulation of educational perspectives from Portuguese physical education cooperating teachers at distinctive professional stages, according to teaching and mentoring experience. Two main topics superintend the query, which was intended to answer the objectives of teacher's education programs and teachers' role. Data for this study were collected from open-ended interviews from 30 participants (10 with short teaching experience; 10 with short mentoring experience; and 10 with long mentoring experience). The qualitative analysis consisted of coding the text attached to the two main topics. The coding process included the active search of themes and patterns emergent from cooperating teachers' transcripts. Results reported by cooperating teaching group made apparent the influence of professional experience but also a general agreement about the teacher profile. The guidelines for teacher training programs in Portugal, such as the case of Physical Education, show event interrelationship's perceptions in a real context, oriented by values inherent to the acquisition and transformation of new knowledge and development of educational skills. Conclusions supported that the teacher's role is increasingly demanding, and thus his formation claims a pattern of increasing quality.
\end{abstract}

Keywords: Learning, physical education, student, teaching.

\section{INTRODUCTION}

One of the main challenges society faces is the quality of education. It seems clear that one of the few areas in wich we can still find some kind of consensus is the relevance of the teacher's role in the educational process. However, this consensus does not extend to teacher education (TE). At odds with some prestigious professions, which strongly hold shared values and norms, TE programs reveal different conceptual orientations, reflecting a considerable diversity of values, objectives, and contents.

Surely, it is expected that TE incorporate conceptions, attitudes, and tools (working methods and pedagogical practice experiences) conducive to learning processes for prospective teachers. Most of the TE programs prize an idea of competence development focused on reflective analysis and ethicalresponsibility, as an essential basis for the profession's competent performance [1].

Thus, in order to ensure good teachers in each classroom, it is necessary to understand that "The quality of an educational system cannot exceed the quality of its teachers", as stated by a South Korean educational manager in an interview for McKinsey \& Company consulting report. This report tried to analyse the practices of the countries with the best educational system (Canada, Australia, Belgium, Finland, Hong Kong, Japan, Netherlands, New Zealand,

*Address correspondence to this author at the Av. Carlo Oliveira Campos, Castelo da Maia 4475-690 Aviso S. Pedro University Institute of Maia; Tel: +351 2298253191, +351 229866000; Fax: +351 229825331;

E-mail: aalbuquerque@ ismai.pt
Singapore and South Korea) and what do they have in common [2]. Two of the main findings in this report indicate that all these countries manage to select and train the right people to become teacher, and to promote its development, in order to become best practice teachers.

According to an OECD study (2005) [3], the overall priority of educational managers should be to clearly and concisely define what is expected regarding the knowledge and the skills of teachers, i.e., setting standards for a good teacher. Although this is not a simple task, the idea is that the definitions of these standards provide a landmark to guide policies for selection, training, assessment and development for the teacher career. Some countries worked their way in that direction, by structuring patterns for the teaching profession. And, no matter how different their social and educational system contexts or the way they assess the teaching patterns, several factors that are part of a good teacher profile recur among these countries, such as: Australia, Canada, Singapore, Chile, Cuba, United States of America and England. Some of the main factors are:

1. He masters the program of the disciplines he teaches, including an understanding of its principles and concepts.

2. He knows the characteristics of students' development, their experiences, and the context they live in, and how these factors influence their learning.

3. He masters the didactic of the disciplines he teaches, including the several strategies and teaching activities. 
4. He masters the curriculum and curricular guidelines of the disciplines he teaches.

5. Organizes objectives and contents in a way consistent with the curriculum, the moments of student development and their level of learning.

6. Select learning resources according to the learning objectives and the characteristics of his students.

7. Selects assessment strategies in accordance with the learning objectives, the discipline he teaches, and the curriculum, enabling all students to show what they have learned.

8. Establishes learning friendly environment, based in relations of respect, fairness, trust, cooperation and enthusiasm.

9. Expresses high expectations on the possibilities of learning and development of all its students.

10. Establishes and maintains standards of sociability in the classroom, so that students learn to take responsibility for their learning and that of their colleagues.

11. Demonstrates values, positive attitudes and behaviours, and promote its development by students.

12. Communicates effectively with parents, updating them and trying to ensure their commitment with the teaching process and student's learning.

13. Applies challenging strategies coherent with the learning objectives and the different student's level of development.

14. Uses methods and procedures promoting the thinking development and the independent search for knowledge.

15. Optimizes the available teaching time, ensuring the maximum learning for each student during class.

16. Evaluates and monitors the student's contents perception and appropriation process.

17. Seeks constantly to improve his work from various practices, such as systematic reflection of his performance, self-assessment in relation to student progress, the recent research findings on his area of expertise, and recommendations from supervisors, mentors and colleagues.

18. Work together with other professionals to make decisions regarding construction and / or implementation of the curriculum and other school policies.

19. Possesses updated information about the responsibilities of his profession, including the information related to the pupils learning and wellbeing.

20. He knows the educational system and current policies.

These standards underscore the importance of valuing the identity of the teacher as someone who needs the specific knowledge and skills for his professional practice, which cannot be replaced by mere willingness or desire to work with children.

In order to ensure good teachers in each classroom, we need to attract candidates with great potential to achieve this desired profile for teaching, so that we can select the best candidates, as it happens in the above mentioned countries which have the best educational systems.

Unfortunately, in Portugal teaching has not been seen as an attractive career for citizens. According to a recent study [4] about pre-socialization, the students, Physical Education aspiring teachers, report transformations on their conceptions throughout FI, but not in the sense of more holistic and integrative conceptions about the "Physical Education and Sports" or the "competent teacher".

It was concluded that the student interns have adopted a conception of Physical Education more focused on technical aspects, gradually losing the conception centred on aspects of ethical and relational nature, which may be compromising for what is the effective role of the teacher.

In Brazil, according to a recent Carlos Chagas Foundation research, with a sample of 1500 high school Brazilian students of eight cities, the students recognize the profession's social function, and they believe it's a noble and gratifying job, nevertheless they point out the disparity between the profession's demands and feedback. The students find the job very difficult, and at the same time they find teaching social and financially devalued.

General guidelines for the Physical Education Teacher Education programs (PETE) in Portugal emphasize rich experience in real learning situations, oriented by values inherent to the acquisition and transformation of new knowledge and development of teaching skills.

So, the development of such assets could be enhanced by infusing investigative and reflective practices into the learning experience, aimed at nurturing the senses of individuality and identity, in the context of concrete, meaningful situations [5].

These assumptions take PETE as a space for transformation and emancipation of the individual prospective teacher [6]. In this context, most of the intervention strategies put forward by PETE programs consider the circumstances where learning develops, and seeks to integrate and interconnect the various areas and fields of knowledge relevant to PETE, in order to avoid formalism and conversely to maximize significant experiences that lead to professional growth of future teachers. Furthermore, two aspects need to be considered: (i) the nature of the subject matter knowledge for which the training proposal is directed; (ii) the learning experiences rooted in current educational paradigms and training models with a close link with the school dynamic realities.

In fact, the implementation of national educational policies is ultimately influenced by the perspectives of teachers, as critical agents in the classrooms. Teachers interpret the national curriculum and mediate the students' day-by-day learning according to their own beliefs and personal sense of duty, which were filtered by ideological 
Table 1. Participant's characteristics.

\begin{tabular}{|c|c|c|c|}
\hline & Teaching Experience & Mentoring Experience & Men/Women \\
\hline \hline Short Teaching Experience & 3 to 9 years & 1 to 3 years & $8 / 2$ \\
\hline Short mentoring Experience & 11 to 18 years & 4 to 5 years & $8 / 2$ \\
\hline Long mentoring Experience & 13 to 26 years & 8 to 11 years & $4 / 6$ \\
\hline
\end{tabular}

criteria. If schools were to prepare students enjoying full citizenship and equal opportunities, it is necessary that PETE responds and corresponds to this purpose.

However, PETE seems to be still in an undeveloped stage, whether by the lack of research support, or excessive political changes that permanently alter the parameters of teachers work, or both aspects simultaneously. The constant change in the law that regulates the working conditions, as well as the increase in the number of students per class, or the lower number of hours devoted to Physical Education (PE), or the cut-off of the PE assessment either for the student's final marks or for the access to higher education, have been difficult obstacles to overcome, in order to reach a definition of a PE teacher profile. However, we consider that this profile should be for the teachers and not specifically for the PE teachers, having obviously in mind the differences inherent to each subject matter's particularity.

It is, therefore, necessary to redeem the discussion on the desired profile for the tomorrow's teachers, forecasting themes actors of competent teaching, honest, friendly, confidence-inspiring, available, demanding, empathetic and fair educators [7].

The practicum is par excellence the key socialization agent within TE programs, once it embodies the first experiences of pedagogical intervention, which opens to the prospective teacher the insider world of teachers. The supervised teaching practice has the potential to strengthen the connection between university and school, and so calling into question the Zeichner's (1993) opposed processes oflearning by osmosis from practical exposure vs. a conceptually structured intentional orientation and pedagogic supervision [1].

In this perspective, and as stated in the relevant literature [7-11], we must agree that cooperating teachers play a key role in teachers training, and their perspectives should be considered in any attempt at organizing and setting goals for the training of teachers.

With this study, we therefore intend to understand how cooperating teachers express themselves about two leading topics of TE programs, TE objectives and Teachers' roles. Through the thoughts about competence and knowledge of the craft it is possible to examine how they position themselves against the themes which outline the conceptual guidelines of their action; or to know that theco-operating teachers focus on mentoring, on student teachers' learning process, and on the preferred way of teaching.

\section{METHOD}

\subsection{Participants}

A preliminary examination of the cooperating teachers' characteristics in the region of Oporto put in evidence the heterogeneity of their professional experience, both as cooperating teachers, and as Physical Education teachers.

A stratified purposeful sampling strategy allowed to set out 30 cooperating teachers, about $40 \%$ of the cooperating teacher s' universe, and to distribute them into three clear-cut groups, made different from each other, firstly by the criterion of mentoring experience, and then according to their teaching experience. Ten participants by group provided a trustworthy figure enabling the possibility for a scrutiny of professional experience influence in both mentoring and teaching experiences.

Seeking for the maximum distinction between the 3 groups we defined as cut-off values, 6 years for the mentoring experience, and 10 years for teaching experience (Table 1).

Data were collected by applying a structured open-ended interview protocol, whose questions were based on the Grossman's model [12] of professional knowledge for teaching.

The questions sought to characterize the conceptions of cooperating teachers about the objectives of the practicum, and the ideal profile to practice the profession. The responses were recorded, transcribed verbatim, and brought into qualitative analysis software NVivo 10.

The qualitative data analysis was supported by the Feiman- conceptual orientations in teacher education [13]. The first phase of the analysis consisted of coding the interview. Text before hand attached to two main topics deduced from the conceptual framework: "Objectives of PETE" and "Role of the Teacher". The coding process included the active search of themes and patterns emergent from cooperating teachers' transcripts. The analysis was developed, firstly within each orientation group, and findings were discussed across all groups.

Regarding the Objectives of PETE, we attempted to bring together the material related to the general educational principles and to the major PETE guidelines. We retained the ideas that cooperating teachers expressed about the competence, the tools of the trade, and knowledge of the craft, so that future teachers might become specialized subjects in the task of teaching. 
Table 2. Group 1 - objectives of PETE and teachers' role.

\begin{tabular}{|c|c|}
\hline - Preparing dedicated teachers & $\begin{array}{l}\text { - Dignify Physical Education } \\
\text { - Make students work } \\
\text { - Make Physical Education pleasant } \\
\text { to students }\end{array}$ \\
\hline - Preparing plain teachers & $\begin{array}{l}\text { - Teach } \\
\text { - Give lessons }\end{array}$ \\
\hline $\begin{array}{l}\text { - Preparing positive classroom } \\
\text { animators }\end{array}$ & $\begin{array}{l}\text { - Mobilizing students } \\
\text { - Teach knowledge-based teaching } \\
\text { - Boost school } \\
\text { - Physical Education give a valid } \\
\text { picture }\end{array}$ \\
\hline $\begin{array}{l}\text { - Preparing enthusiastic } \\
\text { teachers }\end{array}$ & $\begin{array}{l}\text { - Learn how to engage } \\
\text { - Captivate students } \\
\text { - Manage the classroom and student } \\
\text { behaviour } \\
\text { - To become a part of the school }\end{array}$ \\
\hline $\begin{array}{l}\text { - Preparing trust worthy } \\
\text { teachers }\end{array}$ & $\begin{array}{l}\text { - Giving good lessons } \\
\text { - Solving problems of the practice }\end{array}$ \\
\hline
\end{tabular}

On the second topic, the Teacher's Role, we attempted to gather material providing evidence on how cooperating teachers envisage the teacher's presence in the pedagogical relationship; what does it mean to be a teacher and to act as a teacher. We retained here the cooperating teachers' references on the attitudes and skills that student teachers should pursue to become teachers who are able to articulate goals, choose appropriate teaching strategies, support students' social experiences and cognitive orientations, or coordinate their actions. The teacher's role configuration comprises the ideas on how teachers understand the learning activity and its social and political contexts, how do they design learning experiences in order to improve students' skills, knowledge, and dispositions, and how they invest professionally on the improvement of their teaching, the curriculum, and doing so, the schooling experience and the quality of education for their students [14].

\section{RESULTS}

In the following subsections of results, the categories emergent within the main topics of the analytical framework, objectives of PETE and teacher's role, are presented and analysed by cooperating teachers' group.

\subsection{Cooperating Teachers with Short Teaching Experience}

The Practicum was undertaken by all cooperating teachers of this group as a decisive professional development moment, marked by its practical experience, focused primarily on teaching. Table $\mathbf{2}$ exhibits the categories of objectives of PETE and teachers' roles emergent among this group of Cooperating teachers with short teaching experience.
The teacher was perceived essentially as a practical professional, who has to apply a body of knowledge, but fundamentally respond to the specific challenges posed by the school and the students. He has to acquire and develop a set of management skills, discipline, personal relationship, planning and instruction, and should have a worthy professional attitude.

I find it very important that the student teacher tries to change the image of physical education teachers in school. In terms of the teacher's attitude in the class: To know how to position himself before the students in the classroom, to know how to use the space as best as possible, to know how to maximise the space, to know how to organize the class, to know how to convey knowledge, to know how to provide feedback. This is what worries me, very, very much. [Sofia, section 1, paragraph 5].

The PETE objectives and the conception of the teacher's role discernible in this group of cooperating teachers emphasised the making of self ideas about the meaning of the Practicum process, and the figure of teacher cooperating teachers try to deliver to their student teachers. For example, for some cooperating teachers, enjoying classes, liking the teacher, and being able to establish a positive pedagogical relationship are the keys for educational success.

In order for students to like[classes], it is necessary to create dynamic interpersonal relationships. I value the ability to boost a particular classroom environment. I think a class is positive and becomes a privileged place of learning for students, if they are motivated and involved in the class, not only amongst them, but especially involving students and teachers; in order to create an environment, an environment that is ... ok, let's call it joyful, light, but at the same time responsible, and that will lead them to do what the teacher wants them to do in order to learn. [Philip, Section 8, paragraph 38].

As much as they [students] like, there are always doing something that sometimes we don't like. And then it seems like everything goes wrong, perhaps it goes wrong because we started bad and not because the student started bad. (...). Whenever I speak with the student teachers, I say this, ... if anything we have difficulty on is human relation. So, the more we work human relations, the more we'll be able to attract students. It's easier to make them liking school, after they like us. Essentially, it's, I think, what's the most worrying in the mentoring of student teachers. [Daniel, section 1, paragraph 7].

The extent, to which these images are linked to the PETE objectives, and what is its actual consequence in guiding the Practicum process, are important issues. Either way, the cooperating teachers did not associate their images to any educational guiding idea established by the University, from which they claim for more proximity and support.

I do not see any big problem [in the functioning of the Practicum]. I think there may be less distant from the University, a triangle, University, mentoring, student teachers. We're open, so this gives us a margin. It's good but on the other hand it is bad. I think the University today is flexible with the cooperating teacher, the supervisor, the 
Table 3. Objectives of PETE and teachers' role of cooperating teachers with short mentoring experience.

\begin{tabular}{|c|c|}
\hline $\begin{array}{l}\text { - Prepare the open-minded } \\
\text { teacher }\end{array}$ & $\begin{array}{l}\text { - Know how to interact } \\
\text { - Understand "the reason of practical } \\
\text { things" } \\
\text { - Be upright both in life and profession } \\
\text { - Is open to learning }\end{array}$ \\
\hline $\begin{array}{l}\text { - Prepare the competent and } \\
\text { passionate teacher }\end{array}$ & $\begin{array}{l}\text { - Organize and plan his teaching } \\
\text { - Work for abetter environment }\end{array}$ \\
\hline $\begin{array}{l}\text { - Prepare the motivated and } \\
\text { active teacher }\end{array}$ & $\begin{array}{l}\text { - Show dedication in teaching } \\
\text { - Value the pedagogical practice } \\
\text { - Be integrated in the school } \\
\text { community }\end{array}$ \\
\hline - Prepare a good teacher & $\begin{array}{l}\text { - Plan and coordinate the process of } \\
\text { teaching and learning } \\
\text { - Manage the development of students } \\
\text { - know the school well }\end{array}$ \\
\hline $\begin{array}{l}\text { - Prepare an school all time } \\
\text { teacher }\end{array}$ & $\begin{array}{l}\text { - Remain in school beyond classes } \\
\text { - Create a good physical education } \\
\text { image in school } \\
\text { - Drive activities at school }\end{array}$ \\
\hline
\end{tabular}

student teacher. Gives us room to move our way. Is it good or bad? It's a double-edged sword. [Alberto, section 11, paragraph 40].

I feel that I'm often in conflict with them, in some respects. We should be able to obtain information from the University, the way in which student teachers dealt with matters internally. Obviously, from discussion things get clear and conclusions are reached. But I notice that their preparation in specific modalities is very different from the preparation I had. And if I want to help them with the selection of learning tasks and their application form, what's the best way to approach that content? Once I do not have the same information they received, sometimes I can't. I cannot attend to their needs in the best way. [Sofia, section 10, paragraph 40].

\subsection{Cooperating Teachers with Short Mentoring Experience}

As it happened in previous studies [7], we came across with a wide variety of opinions. There were cooperating teachers in this group with a high level of motivation and others who are strict, thereby assuming the notoriety of some aspects grouping around the same feeling, the conceptions about being a teacher at school nowadays.

Table 3 display the key themes and patterns emergent in the analysis of conceptions of cooperating teachers with short mentoring experience in what concerns PETE objectives and teachers' role.
The teacher was perceived as romantic and somehow utopian, directing his actions not based on the possibility to carry forward a real project, but rather based on what he believes is ideal, regardless of being or not feasible.

This is the period of teachers' development, which Sikes (1985) refers to as the third phase of the teachers life cycles, characterising this teacher's sample (all between 30 and 40 years) as bearers of great physical and intellectual capacity, which means energy, involvement, ambition and selfconfidence [15].

The teacher must know how to understand the school, know how to integrate the school environment; know how to understand students, know that probably the set of tools assimilated at college may not be enough for his daily routine. And he should be able to adapt himself depending on the experience accrued. [Sebastião, section 1, paragraph 7].

Normally students and even some fellow trainees come here to erroneously think the profession and work at school. I think that the work of each one of us is everything else beyond classes, it has to do with carrying out activities, with the image that one's able to create around physical education, with the connection established with students, which is far beyond school terms. That's why I say that I like our schedules to be as irregular as possible to force them to come to school often. They know they have to be acquainted to everyone at school, they have to adapt well to school. I think this is the main aspect, because giving physical education classes per se will not make a difference, the difference should be extra classes. [Carlos, section 1, paragraph 7].

In this group of cooperating teachers, the fulfilment of essential tasks for the teaching objectives seemed to achieve consensus. The aspects related to the presence at school, commitment to the cause, to know how to behave, became very important and are fundamental keys in this group of cooperating teachers. For them the teacher's success is largely determined by the level of integration in the school's environment.

... I am an educator, a colleague, an individual who, in the next twenty-five thirty years, will be teaching, reason why my personal signature as cooperative teacher, I do care to give student teacher a life overview, much more than to be concerned with a classification, much more that he understands the feedbacks and their importance, the importance of good relations and management, it is also important to learn how to have a good relationship with the students, with the school, with life and above all my goal is that the practicum is a moment, another moment of life, of learning, that is my perspective. [João, section 1.1, paragraph 7].

During practicum I think it is important to face the reality of school in its various aspects, relationship with colleagues, working in the school ... and especially ... teaching subject matter in a positive, interesting capable manner. So I think 
Table 4. Objectives of PETE and teachers' roleof cooperating teachers with short mentoring experience.

\begin{tabular}{|c|c|}
\hline $\begin{array}{l}\text { - Prepare the dedicated } \\
\text { and efficient teacher }\end{array}$ & $\begin{array}{l}\text { - Have a proper professional performance, } \\
\text { not to "sell a couple of hours" } \\
\text { - Plan, execute and reflect on ones teaching } \\
\text { - Stimulate and participate in school } \\
\text { activities and physical education group }\end{array}$ \\
\hline $\begin{array}{l}\text { - Prepare the decision } \\
\text { maker teacher for the } \\
\text { benefit of students }\end{array}$ & $\begin{array}{l}\text { - Manage the classroom space in a } \\
\text { profitable way } \\
\text { - Teach something that students might use } \\
\text { in the future }\end{array}$ \\
\hline $\begin{array}{l}\text { - Prepare the efficient and } \\
\text { reasoned teacher }\end{array}$ & $\begin{array}{l}\text { - Organize and substantiate the teaching } \\
\text { practice } \\
\text { - Plan and evaluate rigorously the process } \\
\text { of teaching and learning } \\
\text { - Effectively manage the classroom } \\
\text { - Develop projects beyond the classroom, } \\
\text { directing class }\end{array}$ \\
\hline $\begin{array}{l}\text { - Prepare the interested } \\
\text { teacher }\end{array}$ & $\begin{array}{l}\text { - Set a goal for physical education in } \\
\text { school } \\
\text { - Gain the trust of students } \\
\text { - Be available to school }\end{array}$ \\
\hline $\begin{array}{l}\text {-Prepare the responsible } \\
\text { teacher }\end{array}$ & $\begin{array}{l}\text { - Focus on teaching practice } \\
\text { - Take part in the school community }\end{array}$ \\
\hline
\end{tabular}

that Practicum should focus mainly on the activity in class. Obviously the teacher is not only a teacher to be in class, he has a whole school community to inter-relate with, and I think that in this respect it is also important that the student teacher goes and learns to move within this reality. [Francisco, section 1, paragraph 5].

\subsection{Cooperating Teachers with Long Orientation Experience}

For this experienced cooperating teachers group, the practicum appears as a privileged moment of socialization of new teachers in the school. This world is seen as the reality as opposed to previous campus and early field experiences, which do not conveniently prepare teacher candidates to the shock of practice [16].

Table 4 synthesises the main themes and patterns related to this group views on PETE education objectives and teachers' role-

The gap between theory and practice is vividly patent in the words of a senior cooperating teacher:

It's all too fictional, in terms of university, all very unreal. They leave campus without concrete notions. That's it. And afterwards the school is the stark reality. Managing the classroom, discipline, and then all the things teachers have to give to students. [Susana, section 1, paragraph 5].
Also for this group, the class cumulates the major concerns on monitoring and supervision of student teachers. The teacher is a practitioner, whose role is to adapt the academic knowledge to the reality of the class and to the specific teaching situation conditions, and to learn a set of concepts and teaching procedures that only experience can provide.

What I want is that they adapt the knowledge they have to the present reality, because that's the most difficult. I think my work is mainly about teaching practice. The pedagogical practice to which I am referring is no recipe on how is the best way to teach, but instead that they can adapt what they have learned in college according to the material and human conditions and students they have. [Rute, section 1, paragraph 5].

They now come from college with a good scientific knowledge, so I think the educational part is very important. The pedagogical aspect will be a contribution for the individual to be a more competent person and for him to acquire other parameters such as responsibility, critical thinking, and interconnection capacity with students, with school, with the environment. Apart from these factors, there are many factors that contribute to it. [Mário, section 1, paragraph 6].

Cooperating teachers of this group sought to project their own ideas of professionalism and dedication to the school, in the relationship established with their student teachers, by combining an efficient socialization purpose, i.e., of smooth integration within a school with a moral linking purpose to a professional attitude. For example, Paulo emphasises the main helping nature of the teaching profession, with students at a permanent and irreplaceable horizon that justify all the actions.

My speech, throughout the year is in a way that I would call humanist, progressive, and helpful. That is: humanist, because of what we really do here at school, which is not what we require students to comply, but instead what we must comply for them; secondly all student teacher's actions should be in accordance with the students' needs, specifically the preparatory work, regarding lessons planning. That is, the written material that they might include in their planning and the oral speech they might present to their students, not because of themselves, or the school. [Paulo, section 4, paragraph 17].

Diana, on the other hand, emphasises the professional honesty, which in her view is based on a pedagogical rationality founded in an effort of assessment transparency, as a guide and touchstone of a deliberate and consequential activity.

To assume ones responsibilities, to be on time, to be diligent, to be really encouraging. Furthermore, to be responsible whenever possible, in pedagogical-didactic terms, in terms of development of teaching and learning. Mainly in terms of assessment, which I think is one of the most sensitive points and in which I really insist. I keep insisting in the transparency of the evaluation (...) and if they look for the 
process guidance in this perspective, with all these really important issues, I think people will become honest and really consequential in what they do and in what they say. [Diana, section 4, paragraph 16].

\section{DISCUSSION AND CONCLUSION}

This study aimed at finding an articulation of educational perspectives from physical education cooperating teachers at distinctive professional stages, according to teaching and mentoring experience. Two main topics superintend the query, which was intended to answer to the PETE objectives and to teachers' role, i.e. the competencies underlying the desired profile of Physical Education teacher.

When looking from the different groups of cooperating teacher's point of view, it seems we can conclude that for the cooperating teachers with short teaching experience, the major vector of the role that teachers should play inside school should focus on work in the classroom, in their efficiency, and competence and represents their main goal.

The knowledge and encouragement of the school community is the background for cooperating teachers with short mentoring experience. Significant references also appear such as teaching planning and organization, and residual aspects related to the decision in the act of teaching, with reflection on practice, teaching differentiation, and professional integrity.

For cooperating teachers with long orientation experience, the main focus is the one associated with the functioning of the disciplinary group in the programmatic decisions aspects, as it may involve direct and future benefit to students.

In sum, there is an obvious evolution from the particular to the most comprehensive and integrative aspects of the performance of a teacher's function at school. This growing evolution appears from less experienced cooperating teachers to more experienced ones. The voice of experience is obvious to the range of professionalism. Experience permits some kind of liberty for the specific tasks in the classroom, which favours the appearance of more axiological concerns over the professional performance of teachers.

Moreover, this study seems to support a near-consensus amongst all the interviewed cooperating teachers over a sketchy conception of "a good teacher", which included a diversified yet simultaneously unified set of characteristics around a profile of a dedicated, practical, positive class stimulator, captivating, open minded, competent, passionate, proactive, motivated, rigorous, available, efficient, decision maker, reasoned, interested, and responsible teacher.

The reflection on teacher profiles and desired teaching practices put the demand for professionalism at the centre of the problem of initial TE, in the context of education and teacher education systems [17]. Leitere cognises that being a teacher is increasingly demanding, and for that reason TE requires a pattern of increasing quality "expanding beyond the initial training and to fields beyond the boundaries of disciplinary knowledge that each one is bound to, while taking them into account". Being a teacher is difficult, getting increasingly more and more difficult.

The findings of this study pointed to the importance of developing thematic queries into the complexity of TE programs, in order to grasp the representations and commitments of key actors on their way to achieve educational expertise. Such queries, inspired on a social constructivist approach, will find their basis in a transformative educational perspective as opposed to a reproductive perspective, and will involve the idea of "empowerment" based on ideological formation processes.

\section{CONFLICT OF INTEREST}

The authors confirm that this article content has no conflict of interest.

\section{ACKNOWLEDGEMENTS}

Declared none.

\section{REFERENCES}

[1] Zeichner K. A critical analysis of reflection as a goal for teacher education. Educação e Sociedade 2008; 29(103).

[2] Giambona F, Vassallo E, Vassiliadis E. Educational systems efficiency in European Union Countries. Stud Edu Eval 2011; 37(2-3): 108-22.

[3] OECD, OECD publications. Annual Report. France; 2005.

[4] Albuquerque A, et al. Evolução das perspectivas profissionais dos alunos de educação física e desporto durante a sua formação inicial nos sectores público e privado, in Educação Física, Desporto e Lazer. Perspectivas luso-brasileiras N. Fumes, L. Santiago, and A. Albuquerque, Editors. edUFAL e Edições ISMAI.: Maceió, Alagoas - Brasil; 2012, pp. 47-62.

[5] Durand M, Saury J, Veyrunes P. Relações fecundas entre pesquisa e formação docente: Elementos para um programa. Cadernos de Pesquisa; 2005; 35(125): 37-62.

[6] Moreia M, Vieira F. Supervisão e avaliação do desempenho docente. Para uma abordagem de orientação transformadora. Ministério da Educação, Conselho Científico da Avaliação de Professores: Lisboa; 2011.

[7] Albuquerque A, Graça A, Januário C. A supervisão pedagógica em Educação Física: A perspetiva do orientador de estágio.Lisboa: Livros Horizonte; 2005.

[8] Harrison J, Lawson T, Wotley A. Facilitating the professional learning of new teachers through critical reflection during mentoring meetings. Eur J Teach Edu 2005; 28(3): 267-92.

[9] Portelance L. Une analyse des manifestations du dialogue collaboratif entre enseignant associé et stagiaire, in La collaboration dans le milieu de l'éducation: Dimensions pratiques et perspectives théoriques, L. Portelance, C. Borges, and J. Pharand, Editors. Press Universitaires du Québec Québec 2011.

[10] Sim C. Preparing the professional experiences incorporating preservice teachers as communities of service. Teach Teaching Edu 2006; 22(1): 77-83.

[11] Tardif M, Borges C. Évolution du métier d'enseignant et travail partagé. Science de l'éducation - Pour l'Ère nouvelle 2009; 42(2).

[12] Grossman, P. The making of a teacher. Teacher and Teacher Edu. New York: Teachers College Press; 1990.

[13] Feiman-Nemser S. Teacher preparation: Structural and conceptual alternatives, in Handbook of Research on Teacher Education, R. Houston, M. Haberman, and J. Sikula, Editors. MacMillan: New York; 1990; pp. 212-33. 
[14] Marcelo G. Formação de professores: Para uma mudança educativa. Porto: Porto Editora, 2005.

[15] Sikes P. The life cycle of the teacher, in Teacher's lives and careers, S. Ball and I. Goodson, Editors. The Falmer Press London 1985; pp. 67-70.
[16] Schoolteacher L. A sociological study. Chicago: University of Chicago Press: 2002

[17] Leite C. Percursos e tendências recentes na formação de professores em Portugal. Educação; XXVIII(9) 2002; pp. 371-89.

(C) Albuquerque et al.; Licensee Bentham Open.

This is an open access article licensed under the terms of the Creative Commons Attribution Non-Commercial License (http://creativecommons.org/licenses/ by-nc/3.0/) which permits unrestricted, non-commercial use, distribution and reproduction in any medium, provided the work is properly cited. 